\title{
Introduction of Obligation to Undergo a Medical Examination, Preventive Activities, Drug Addiction Treatment and (or) Medical and (or) Social Rehabilitation Due to Use of Narcotic or Psychotropic Substances Without Medical Approval \\ or new Potentially Hazardous Psychoactive Substances as a Countermeasure Against the Drug Threat: Prospects and Problems of Implementation
}

\author{
Nikolay N. Tsukanov* \\ Siberian Federal University \\ 79 Svobodny, Krasnoyarsk, 660041, Russia
}

Received 18.06.2015, received in revised form 21.07.2015, accepted 17.09.2015

The present article considers the issues associated with the implementation of part 2.1 article 4.1 of the Administrative Offences Code of the Russian Federation that states that when imposing an administrative penalty for the administrative offence in the field of the legislation concerning narcotic drugs, psychotropic substances or any precursors thereof on a person recognized as a drug addict or a person consuming narcotic drugs or psychotropic substances without medical approval or any new potentially hazardous psychoactive substances, the court may oblige such a person to undergo a medical examination, preventive activities, drug addiction treatment and (or) medical and (or) social rehabilitation due to the consumption of narcotic drugs or psychotropic substances without medical approval or any new potentially hazardous psychoactive substances.

The present article analyzes the problems that occur in the practice of the drug control agencies, formulates the possible solutions and assesses their prospects.

Keywords: medical examination, preventive actions, drug addiction treatment, medical rehabilitation, social rehabilitation, narcotic drugs, psychotropic substances, new potentially hazardous psychoactive substances, drug threat.

DOI: $10.17516 / 1997-1370-2015-8-10-2116-2130$

Research area: law.

Introduction to the problem. The legislative acts of the Russian Federation"1, Federal Laws No 313-FZ of November 25, No.7-FZ of February 3, 2015 "On introducing 2013, "On introducing amendments to certain amendments to certain legislative acts of the

(c) Siberian Federal University. All rights reserved

* Corresponding author E-mail address: Post@sibli.ru 
Russian Federation"2 complete article 4.1 of the Administrative Offences Code of the Russian Federation with Part 2.1, that states that when imposing an administrative penalty for the administrative offence in the field of the legislation concerning narcotic drugs, psychotropic substances or any precursors thereof on a person recognized as a drug addict or a person consuming narcotic drugs or psychotropic substances without medical approval or any new potentially hazardous psychoactive substances, the court may oblige such a person to undergo a medical examination, preventive activities, drug addiction treatment and (or) medical and (or) social rehabilitation due to the consumption of narcotic drugs or psychotropic substances without medical approval or any new potentially hazardous psychoactive substances.

The mentioned regulation is one of the means of implementation of the Strategy of the Russian Federation National Anti-Drug Policy ${ }^{3}$ and assumes a new level of cooperation between the law enforcement and judicial bodies, medical organizations and social rehabilitationinstitutions. But as the innovation entered into force only on May 25, 2014, the level of its theoretical understanding and practical implementation still remains minimal. As remarked by A.Z. Kilin, by January 1, 2015, the courts of Krasnoyarsk Region had delivered only 149 rulings on the imposing of administrative penalties under part 2.1 article 4.1 of the RF Administrative Offences Code (35\% of the administrative cases under Article 6.9 of the Administrative Offences Code considered within the same period $)^{4}$. By February 6, 2015, the number of such decrees had reached 184 , which also constituted $35 \%$ of the administrative offences cases under article 6.9 of the RF Administrative Offences Code considered within the same period ${ }^{5}$. And even though at the present moment some efforts are made to expand the application of part 2.1 article 4.1 of the RF
Administrative Offences Code, there is still a lot to be done.

Today one can only state the presence of separate attempts to analyze different ways of encouraging the treatment and rehabilitation of drug addicts and narcotic drug consumers. For instance, there are some research works studying the general issues of treatment and rehabilitation of drug addicts ${ }^{6}$, the interconnection between the narcotic drug and psychotropic substances consumption and the commitment of other offences and crimes ${ }^{7}$, the problem of deferral of the criminal punishment for drug addicts and the possibility of imposing any obligatory treatment of them ${ }^{8}$, the issues of application of the mentioned measures when imposing any administrative sanctions including other possible means of legal encouragement of treatment and rehabilitation of drug addicts ${ }^{9}$. However, generally there is no adequately developed, thoroughly substantiated and uniformly implemented mechanism of integrated influence on the persons committing criminal offences and being consumers of narcotic drugs, psychotropic substances and any analogues thereof, as well as any new potentially hazardous psychoactive substances, or suffering of drug addiction ${ }^{10}$.

Substantiation of the coercive measure concept. Part 2.1 article 4.1 of the Administrative Offences Code of the Russian Federation determines a specific correlation between the private and the common interests in one of the components of the possible active measures against the drug threat.

According to the experts' opinion, in modern Russia $60 \%$ of injectable drug users do not come into the view of the law enforcement bodies within 3 years after the beginning of consumption ${ }^{11}$. During this time, the drug addiction becomes strong, the health of the drug consumer suffers irreparable damage, and the person commits hundreds of offences and, worst of all, his family 
suffers and new victims get involved into narcotic drug consumption.

In such a situation the revelation of the administrative offence foreseen by part 1 article 6.9 of the RF Administrative Offences Code and the imposing of an administrative fine for illegal narcotic drugs consumption does not serve as an effective means for preventing new crimes that can be committed by this person. Allowing nonmedical drug use, the drug consumer consciously neglects his own health and even life; for this reason, as a rule, he does not take an administrative fine (no matter the amount) much seriously. In our opinion, one can judge of the efficiency of part 1 article 6.9 of the RF Administrative Offences Code only if its application serves as a legal fact that automatically leads the drug consumer to a whole series of adequate and legally significant consequences. At the present moment such consequences are associated, for example, with the possibility of imposing administrative supervision $^{12}$, dismissal of firearms purchase license $^{13}$, of withdrawal of a driving license $\mathrm{e}^{14}$ etc. At the present time, a necessary but still underused measure of law enforcement practice is the efficient treatment of drug addicts.

On one hand, according to the general regulations, medical examination, let alone treatment, requires an informed and voluntary consent to a medical intervention ${ }^{15}$. One should also remember that the Soviet practice of compulsory alcoholism treatment at some labour and treatment facilities caused quite contradictory opinions concerning both the acceptability of such measures and their efficiency. In particular, as it was remarked by N.M. Zhdanov and Iu.P. Solovey, "Only one fifth part of the persons returning from the labour and treatment facilities stay away from alcohol use within a year"16. Drawing intermediary conclusions, on October 25, 1990, the USSR Constitutional Supervision Committee issued Decree No 8 "On legislation concerning compulsory treatment of alcoholics and re-education through labour" that stated that "if not connected to any systematic disturbance of public peace or impairment of rights of other people, avoidance of alcoholism or drug addiction treatment shall not be regarded as an offence causing legal liability. For the same reason, drug consumption as such shall not be regarded as an administrative offence or a crime". In this regard, on December 5, 1991 the RSFSR Law No. 1982-1 "On introduction of changes and amendments into the RSFSR Criminal Code, RSFSR Criminal Procedure Code and the RSFSR Administrative Offences Code" cancelled any criminal and administrative liability for illegal narcotic drugs consumption.

At the present time, this opinion has been reviewed. Article 40 of the Federal Law No.3FZ of January 8, 1998 "On narcotic drugs and psychotropic substances" ${ }^{\prime 17}$ prohibits consumption of any narcotic drugs or psychotropic substances without medical approval in the territory of the Russian Federation; part 3 article 54 of the mentioned Law gives the court an opportunity to oblige a person to undergo drug addiction treatment or assign any other measures foreseen by the legislation of the Russian Federation.

At the same time, the measures foreseen by part 2.1 article 4.1 of the RF Administrative Offences Code are not deemed to be a complete analogue of the compulsory medical measures foreseen by Chapter 5 of the Criminal Code of the Russian Federation. As fairly remarked by Iu.P. Solovey, "the degree of intrusion into the personal freedom of a citizen required for this or that police authority shall be proportional to the social value of the legal objective the authority is provided for" ${ }^{18}$. In this case the person is imposed with an obligation ensured by nothing but the possibility (in the event of refusal to voluntarily fulfil the obligation) of administrative liability application as foreseen by article 6.9.1 of the 
Administrative Offences Code of the Russian Federation ${ }^{19}$.

Problem setting. The analysis of the practical implementation of part 2.1 article 4.1 of the RF Administrative Offences Code as well as the provisions of the current legislation allow us to formulate a series of acute problems requiring some scientific review, and, in some certain cases, a regulatory and legal solution.

1. Insufficiency of the information required by the court for making a motivated decision on the assignment of a certain combination of coercive measures foreseen by part 2.1 article 4.1 of the Administrative Offences Code of the Russian Federation to the person. The decision on the imposing of the appropriate liability to the person issued by the court shall be motivated and individual. Imposing this or that obligation on the person, the judge shall rely upon its true necessity based on the health of the mentioned person in particular. However, the establishment of drug addiction at the current stage is complicated by the provisions of parts 1 and 4 article 13 of the Federal Law No.323-FZ of November 21, 2011 "On the basics of public health of the Russian Federation citizens" that states that the fact of a health encounter, the condition of one's health and diagnosis as well as other information obtained in the process of a medical examination and treatment are regarded as private health information. Disclosure of any private health information without the consent of the citizen or their legal representative is only allowed upon the request of bodies of inquiry, investigation bodies, or the court for the purposes of an investigation or court proceedings, upon the request of the prosecution bodies for the purposes of the procurator's supervision, upon the request of the penal system for the purposes of a criminal punishment execution and the control over the behaviour of a probationer, a convict with a deferred punishment, or a convict released on parole. The request of the drug control bodies carrying out administrative offence proceedings does not serve as grounds for the disclosure of private health information without the citizen's consent. The body that can make such a request in the process of administrative offence proceedings is the court, but it extends the proceedings' time and basically leads to the court's violation of part 4 article 29.6 of the Administrative Offences Code of the Russian Federation ${ }^{20}$.

2. Governmental reaction to the liable person's refusal to fulfil the obligations imposed on them under part 2.1 article 4.1 of the Administrative Offences' Code of the Russian Federation. If the person fails to fulfil the obligations imposed on them on the basis of part 2.1 article 4.1 of the RF Administrative Offences Code, administrative action foreseen by article 6.9.1 of the RF Administrative Offences Code is brought against such person. However, the practice of its application is associated with multiple unresolved issues, such as: a) possibility of bringing multiple administrative actions against the person for the non-fulfilment of the same obligation; b) reaction to the late fulfilment of the obligations; c) subjects enforcing part 2.1 article 4.1 of the RF Administrative Offences Code etc. ${ }^{21}$

3. Interaction between the law enforcement bodies, medical and social rehabilitation institutions. The basic legal acts regulating the interaction are the Administrative Offences Code and the Decree of the Government of the Russian Federation No.484 of May 28, 2014, "On establishment of regulations for the control over the fulfilment of the obligation imposed on a person by the court on undergoing medical examination, preventive activities, drug addiction treatment and (or) medical and (or) social rehabilitation due to narcotic drugs or psychotropic substances consumption without medical approval during the assignment of an administrative penalty"22. 
However, the technical imperfection of the mentioned sources, the necessity to count for a wide range of acts and primarily by-laws ${ }^{23}$ under the conditions of many organizational problems make the implementation of part 2.1 article 4.1 of the Administrative Offences Code even more challenging. For example, the drug control bodies sometimes face the situation when a person addresses the corresponding medical institution long before the arrival of the copy of the judgment in the case on the administrative offence.

The empirical base of the research includes the law enforcement practice results presented by the drug control agencies of Krasnoyarsk Region (234 registered cases) and court institutions (as of 01.01.2015).

Along with the traditional research methods, the authors used of methodological technique based on comparison of the provisions of the RF Administrative Offences Code and the requirements listed in the bylaws (including local ones) regulating the corresponding scope of activities $^{24}$.

\section{Discussion}

1. The analysis of the Krasnoyarsk judges' practice of imposing the obligations foreseen by part 2.1 article 4.1 of the RF Administrative Offences Code prove that the absolute leaders in the category are diagnostics and preventive activities assigned together in the dominating majority of cases. As a rule, the judges are guided by the fact that the proved experience of narcotic drugs, psychotropic substances or new potentially hazardous psychoactive substances consumption serves as sufficient grounds for imposing the obligation to undergo some diagnostics and preventive activities on such persons. However, the drug control agencies have limited access to the health data of the person even concerning the results of the diagnostics imposed on them.
Let us suggest, that, applying part 2.1 article 4.1 of the RF Administrative Offences Code, the judge does not appoint any treatment, but only imposes an obligation to undergo certain procedures on the person. The necessity of treatment is established by the competent medical staff only. At the same time, the judge is not entitled to impose any obligations on the medical organizations. It is evident that the grounds for providing such medical assistance are not the decision of the judge; it is the fact the person requests assistance in order to fulfil the obligation imposed on them by the judge. The medical organization, therefore, does not fulfil the judgement on the administrative penalty, but provides the person with the conditions necessary to fulfil the obligation imposed on them. Consequently, if the diagnostics show that the person suffers from drug addiction, the treatment of such person would be justified. If such diagnosis is not established, the treatment (with subsequent rehabilitation) as such is not carried out even if such obligation is imposed on the person by the administrative penalty judgement. With such an approach, the measures listed in part 2.1 article 4.1 of the RF Administrative Offences Code will be assigned to the dominating majority of people brought to administrative liability, but such measures will be applied only in the presence of some medical and other justified reasons.

The simplified solution or the problem (mostly used in Krasnoyarsk judicial practice) is a variant of imposing liability with the formulation: “... diagnostics, preventive activities, and treatment if necessary...". Though this variant does not completely satisfy the requirements of the legislation, one cannot exclude that it may be useful in the practice of the Supreme Court of the Russian Federation.

We suppose that an efficient solution in the present conditions would be the application of a certain blueprint that would connect 
the assignment of treatment and subsequent coercive measures to the regularity of bringing administrative actions against the person.

A more reasonable solution for the judges in the current legal situation may be found in the discussions and explanatory statements of the Supreme Court of the Russian Federation ${ }^{25}$.

2. In the event of bringing some administrative action foreseen by article 6.9 .1 of the RF Administrative Offences' Code against a person, a reasonable question that arises is the question on the necessity of the subsequent fulfilment of the obligation imposed on the person. At the present moment the judges suggest that it is possible to apply liability under article 6.9 .1 of the RF Administrative Offences Code against a person more than once in the event of nonfulfilment of the obligation once imposed on them. This opinion is based on part 4 article 4.1 of the RF Administrative Offences Code, according to which the assignment of an administrative penalty does not relieve the person of the obligation, the non-fulfilment of which the administrative penalty has been assigned for. Moreover, item 13 of the Order of the Russian Federal Service for Drug Control No. 271 of July 1, 2014 does not foresee such grounds for removing the person from the register as any administrative action foreseen by article 6.9.1 of the RF Administrative Offences Code brought against them. Therefore, a person brought to administrative liability under article 6.9.1 of the RF Administrative Offences Code is not removed from the register, thereby bringing up the issue on the consequences of the offence of the corresponding rules committed by the person.

However, it is not hard to notice that the current legislative acts do not foresee such grounds for deregistering a person as the expiry of the period of limitation. Formally it means that a person hiding from the drug control agencies may stay registered forever, which does not conform to the procedural principles and proves the necessity to improve this part of the legislation.

As for part 4 article 4.1 of the RF Administrative Offences Code, we suppose that such a rule is connected with the obligations established by the regulatory legal acts. For example, the fact of bringing administrative action against an authorized person for the fire safety rules violation does not relieve them of the obligation to fulfil the requirements for the non-fulfilment of which the administrative action has been brought against them. At the same time, if the person does not fulfil the obligation assigned by enabling (individual) legislation, the administrative action can be brought against them only once due to the failure to fulfil the requirements of the mentioned act. For example, the failure to pay an administrative fine only brings a single enforcement of part 1 article 20.25 of the RF Administrative Offences Code; repeated application of the same law to the nonpayment of the same fine is unacceptable. But the ultimate solution of the problem requires either introduction of some details into the current legislation, or a clearly expressed opinion of the Supreme Court of the Russian Federation ${ }^{26}$.

3. Some serious challenges are usually faced in the cases when a person fulfils the imposed obligations, but does it too late. Though the judicial institutions are ready to bring administrative actions against such persons, the research demonstrates that in such situations the drug control agencies prefer drawing up a protocol instead of initiating any legal proceedings.

We suppose that such practice is easily explained from the point of view of the current legislation.

First of all, this issue is directly connected to the problem that unfortunately has not been sufficiently described in literature; this is the problem of the publicity principle, which is, no doubt, typical for the administrative 
offences proceedings, but it is caused by at least one more significant peculiarity. Upon the revelation of the sufficient data proving the fact of an administrative offence related to the jurisdiction of the police officers, the decision on the initiation of proceedings is made on the basis of the reasonability and sufficiency of other non-jurisdictional measures taken by the police, except for the cases explicitly foreseen by the legislation ${ }^{27}$.

Secondly, the circumvention features are formulated in the note to article 6.9.1 of RF Administrative Offences Code. In this regard, to our mind, the expression "does not attend" refers to the situation at the moment of making the decision on initiating proceedings on the administrative offence. Before the clarification of the issue, the legislator or the Supreme Court of the Russian Federation shall follow the literal interpretation, according to which the formulation means that by the moment of inspection carried out by the drug control bodies for the grounds for initiating proceedings on an administrative offence foreseen by article 6.9.1 of the RF Administrative Offences Code, the person has actually not started to fulfil the imposed obligation. If by the moment of such inspection carried out by the drug control agencies the person has actually started to fulfil the obligation, though violating the time it was due, (i.e. attend a medical institution or a social rehabilitation centre, follow the prescription of the consulting physician), then to our mind, there are no more grounds for initiating any administrative proceedings against this person under article 6.9.1 of the RF Administrative Offences Code.

Nevertheless, the mentioned problem also requires some additional scientific review.

4. Some significant challenges are caused by the fact that the internal affairs bodies are not entitled to initiate proceedings on the administrative offences foreseen by article 6.9.1 of the RF Administrative Offences Code. According to part 1 article 29.5 of the RF Administrative Offences Code, an administrative offence case is processed at the place of commitment. In accordance with par.h item 3 of the Decree of the Plenum of the Supreme Court of the Russian Federation No 5 of March 24, 2005 "On some issues experienced by courts applying the Administrative Offences Code of the Russian Federation", at the determination of the territorial jurisdiction of an administrative offence being omission to act in order to fulfil an obligation imposed on a person by a legal act, the law enforcement bodies should be guided by the place of residence of the person. Moreover, if the objective side of the administrative offence is unauthorized abundance of a medical organization or a social rehabilitation institution, or non-fulfilment of the subscription of the consulting physician more than twice, the place of the offence shall be deemed to be the location of such medical organization or social rehabilitation institution.

In accordance with par. 2 part 3 article 25.1 of the RF Administrative Offences Code, upon the proceedings on an administrative offence causing administrative arrest or administrative expulsion from the Russian Federation of a foreign citizen or a stateless person, or compulsory community service, the presence of the person the administrative actions are brought against is obligatory.

Therefore, in order to bring administrative actions under article 6.9.1 of the RF Administrative Offences Code against a person, drug enforcement officers have to travel to the place of residence of the inflictor and there (at the place of the offence commitment) ensure the presence of the inflictor at the hearing on the merits. If necessary, according to articles 27.2, 27.3 of the RF Administrative Offences Code, they are entitled 
request the internal affairs bodies for assistance, but the practice of such cooperation has not been formed by now.

Considering the proportion in the number of staff at the drug control agencies and the internal affairs bodies, the most reasonable solution would be to involve the internal affairs officers into the work, but it requires introduction of some certain changes into the RF Administrative Offences Code.

5. According to item 3 of the Decree of the RF Government No.484 of May 28, 2014, the grounds for the registration of the person with the authorized body is the judgment of the court that has come into legal force. In accordance with the established procedure, such a judgment (with the mark of the court on its enactment) is addressed by the court to the corresponding medical organization or the social rehabilitation institution. However, in practice the person often consults the corresponding institution before the judgment arrives.

The absence of the judgment does not relieve the medical organization of the obligation to provide a patient the required medical assistance. At the same time, the medical organization (rehabilitation institution) obtains certain legal rights and liabilities foreseen by the Decree of the RF Government No.484 of May 28, 2014 after the reception of the enacted judgment of the court on imposing the obligations foreseen by part 2.1 article 4.1 of the RF Administrative Offences Code on the person. For this reason, the medical organizations are not obliged (but are entitled) to inform the drug control agencies on the patients who have been imposed with the certain obligations under part 2.1 article 4.1 of the RF Administrative Offences Code, if the medical institution has not received a copy of the valid court judgment yet.

In similar situations, there are no grounds for registering such persons with the drug enforcement bodies. At the same time the diagnostics, preventive activities, medical and social rehabilitation undergone by the person are accounted for the fulfilment of the obligations imposed on them under part 2 article 4.1 of the RF Administrative Offences Code.

If the person, who requests a medical institution for medical assistance before the arrival of the enacted judgment of the court, leaves the medical institution or the social rehabilitation centre in an unauthorized manner or does not fulfil the prescriptions of the consulting physician more than twice, that the administrative liability foreseen by article 6.9.1 of the RF Administrative Offences Code can be applied to the person only if by the moment the decree has already entered its legal force and if such a decree does not determine a later moment for the fulfilment of the imposed obligation.

The described issue reflects only one of the existing aspects of interdepartmental interaction. However, combined with some other problems, it allows us to judge of the influence made by the legal novelty on the current state of drug consumption.

Conclusion. One should not overestimate the opportunities provided by part 2.1 article 4.1 of the RF Administrative Offences Code to make an impact on the current drug situation. For instance, even by the most conservative estimate, only 500 thousand drug addicts officially registered in Russia commit over 300 million administrative offences foreseen by article 6.9 of the RF Administrative Offences Code. At the same time, according to the statistical report No.4-MB-HOH "Data on the administrative offences connected to the illegal circulation of narcotic drugs, psychotropic substances, precursors and analogues thereof", around 50 thousand proceedings on such administrative offences are initiated by drug control agencies and internal affairs bodies every year. At the 
same time, if we consider the duration and labour intensity of implementing the measures foreseen by part 2.1 article 4.1 of the RF Administrative Offences Code (full cycle may take up to several years), the number of staff and the structure of the drug control agencies (the absence of specialized subdivisions in particular), medical organizations and social rehabilitation institutions, then even this number of revealed drug consumers is too much for the sufficient and timely implementation of the mentioned measures ${ }^{28}$.

The flaws of regulations and law, the problematic issues waiting to be solved are usually compensated by some organizational peculiarities; for this reason, we should not expect the fulfilment of the obligations imposed on the drug addicts under part 2.1 article 4.1 of the RF Administrative Offences Code to become a common and popular thing in the modern conditions. At least at the present moment, the fulfilment of such obligations is often too expensive for the drug addicts and their families (exceeding the amount of the administrative fine foreseen by article 6.9.1 of the RF Administrative Offences Code), while the practice of application of article 6.9.1 of the RF Administrative Offences Code is still very selective.

Nevertheless, there should be no doubt that the changes introduced into article 4.1 of the RF Administrative Offences Code deserve to be positively assessed and the practice of their implementation to be expanded, at least because it evidently requires the changes in the objectives and approaches to the organization of interaction between the bodies that fight against the illegal drugs circulation in the Russian Federation.

1 See: Sobranie zakonodatel'stva Rossiyskoy Federatsii [The Collection of the Legislation of the Russian Federation], 2013. No. 48, article 6161.

2 See: Sobranie zakonodatel'stva Rossiyskoy Federatsii [The Collection of the Legislation of the Russian Federation], 2015. No. 6 , article 885 .

3 See: The Executive Order of the President of the Russian Federation No 690 of June 9, 2010 "On Approving the Strategy of the Russian Federation National Anti-Drug Policy until 2020" // Sobranie zakonodatel'stva Rossiyskoy Federatsii [The Collection of the Legislation of the Russian Federation], 2010. No. 24, Article 3015.

4 See: Kilin A.Z. K voprosu ob aktual'nosti realizatsii na territorii kraia Federal'nogo zakona or 25 noiabria $2013 \mathrm{~g}$. [To the Problem of the Urgency of Implementation of the Federal Law No.313-FZ of November 25, 2013, in the Territory of the Region] // Proceedings of the $18^{\text {th }}$ International Scientific and Practical Conference (April 16-17, 2015) "National and International Levels of Countermeasures Against the Drug Threat and Cooperation in the Field of Rehabilitation and Resocialization of Drug Consumers": in 2 parts. Edited by I.A. Medvedev, Siberian Law Institute of the Russian Federal Service for Drug Control, 2015. Part 2. P. 190.

5 The conclusion of Krasnoyarsk Region Prosecution Office on the results of the implementation of the administrative legislation of February 11-12, 2015.

6 For example, see: Ivanov V.P. Neobkhodimost' sozdaniia novoy sfery reabilitatsii kak otvet na vyzovy sovremennykh obshchest $v$ [The Necessity of Creating a New Sphere of Rehabilitation as a Reaction to the Modern Social Challenges] // Narkologiia 2014, No. 5; Korobitsina T.V. Problemy ispol'zovaniia reabilitatsionnykh tekhnologiy [Rehabilitation Technology Application Challenges] // Razvitie sistemy reabilitatsii i resotsializatsii narkozavisimykh [Drug Addicts Rehabilitation and Resocialization System Development]: educational materials. Irkutsk, 2013; Dimitrova E.A. Analiz deiatel'nosti negosudarstvennykh ob'edineniy $v$ sfere reabilitatsii narkozavisimykh [The Review of Activities Carried Out by NonGovernmental Institutions in the Field of Drug Addicts Rehabilitation]: analytical review. Krasnoyarsk, 2014 etc.

7 Fiodorov A.V. Vzaimosviaz' nezakonnogo potrebleniia narkotikov i ikh nezakonnogo oborota [Interconnection Between Illegal Drug Consumption and Illegal Drug Circulation] // Narkokontrol', 2013, No.3; Dimitrova E.A. Reabilitatsiia narkozavisimykh lits kak mera preduprezhdeniia prestupnosti, sviazannoy s nezakonnym oborotom narkoticheskikh sredsv $i$ psikhotropnykh veshchestv [Drug Addicts Rehabilitation as a Preventive Measure Against Crimes Associated with Illegal Narcotic Drugs and Psychotropic Substances Circulation] // Proceedings of the $17^{\text {th }}$ International Scientific and Practical Conference (April 17-18, 2014) "Current Problems of the Drug Addiction Prevention and the Countermeasures Against the Legal Offences in the Field of Legal and Illegal Drug Circulation: National and International Levels": in 2 parts. Edited by I.A. Medvedev. Krasnoyarsk, 2014, part 2 etc.

8 For example, see: Saiadan S.G. Primenenie otsrochki otbyvaniia nakazaniia bol'nym narkomaniey i novelly rossiyskogo antinarkoticheskogo zakonodatel'stva [Application of Deferral of Punishment to Drug Addicts and Novelties of Russian Drug Law Enforcement] // Meditsinskoe pravo, 2015, No.1; Shchedrin N.V. O prinuditel'nom lechenii lits, stradaiushchikh alkogolizmom i narkomaniey [On Compulsory Treatment of Alcoholics and Drug Addicts] // Narkokontrol', 2013, No.3; Zvonov A.V. Voprosy otvetstvennosti osuzhdionnykh, bol'nykh narkomaniey, otbyvanie nakazaniia kotorym otsrocheno: obshchaia otsenka [General Assessment of Legal Responsibility Issues in Respect to the Convicted Drug Addicts with 
Deferred Penalty] // Ugolovno-ispolnitel'naia sistema: pravo, ekonomika, upravlenie, 2014, No.1; Praktika primeneniia st.82.1 UK RF v 2012 g. (na primere Krasnoyarskogo kraia): otchiot o nauchno-issledovatel'skoy rabote [The Practice of Implementation of Article 82.1 of the Criminal Offences Code of the Russian Federation in the Year 2012 (in Krasnoyarsk Region): Research Report / Siberian Law Institute of the Russian Federal Service for Drug Control; supervised by V.N. Vinokurov, written by D.N. Tokmantsev et al., official registration No. 01201351041. Krasnoyarsk, 2012; Kalachiov B.F. Lechit' nel'zia prinudit' [We Can Treat Not Force] // Narkokontrol', 2013, No.2 etc.

$9 \quad$ Gazizov D.A., Gazizova T.G. Problemy primeneniia zakonodatel'stva ob administrativnykh pravonarusheniiakh $v$ sfere oborota narkoticheskikh sredstv ili psikhotropnykh veshchestv [Problems of Application of the Administrative Offences Legislation in the Field of Narcotic Drugs or Psychotropic Substances Circulation] // Administrativnoe pravo i protsess, 2012, No.3; Tsukanov N.N. Federal'nyy zakon ot 25 noiabria 2013 g. No.313-FZ "O vnesenii izmeneniy v otdel'nye zakonodatel'nye akty Rossiyskoy Federatsii": novoe v administrativno-deliktnom zakonodatel'stve i prognoziruemye problemy pravoprimenitel'noy praktiki [Federal Law No. 313-FZ of November 25, 2013 "On introducing amendments to certain legislative acts of the Russian Federation": Innovations in the Administrative and Tort Law and the Forecasted Problems of Law Enforcement Practice"] // Newsletter of Siberian Law Institute of the Russian Federal Service for Drug Control. 2014, No.1; Tsukanov N.N. Stat'ia 6.9.1 KoAP RF: prognoziruemye voprosy i problemy prakticheskogo primeneniia [Article 6.9.1 of the Administrative Offences Code of the Russian Federation: Forecasted Challenges and Problems of Law Enforcement Practice] // Proceedings of the $17^{\text {th }}$ International Scientific and Practical Conference (April 17-18, 2014) "Current Problems of Preventing Drug Addiction and Counteraction against Offences in the Field of Legal and Illegal Drug Circulation: National and International Levels": in 2 parts / edited by I.A. Medvedev. Krasnoyarsk, 2014, p.2; Novikova T.A. Sovershenstvovanie administrativno-pravovogo mekhanizma vozdeystviia na nezakonnoe potreblenie narkotikov [Improvement of Administrative and Legal Mechanism of Illegal Drug Consumption Treatment]: dissertation for the academic degree of the Candidate of Law. Lyubertsy, 2014; Otkidach A.O. O pravovom mekhanizme pobuzhdeniia $k$ otkazu ot potrebleniia narkotikov i vyboru lecheniia i kompleksnoy reabilitatsii [On the Legal Mechanism of Encouraging the Treatment of Drug Addiction and Selection of Treatment and an Integrated Rehabilitation] // Proceedings of the All-Russian Scientific and Practical Conference of November 26, 2012 "To the 10 $0^{\text {th }}$ Anniversary of the Russian Federal Service for Drug Control. New Legislation and the Challenges of Law Enforcement Practice in the Combat Against Drug Crime", Moscow, part 2. Moscow, 2013; Kodeks Rossiyskoy Federatsii ob administrativnykh pravonarusheniiakh. Glavy 1-10: postateynyy nauchno-prakticheskiy kommentariy [Administrative Offences Code of the Russian Federation, Chapters 1-10: Article-Wise Scientific and Practical Commentary" (edited by B.V. Rossinsky) // SPS Konslutant Plus; etc.

10 For details see: Praktika realizatsii sudami na territorii Kransoyarskogo kraia polozheniy federal'nogo zakona ot 25.11.2013 No.313-FZ. Problemnye voprosy privedeniia meditsinskimi i sotsial'nymi uchrezhdeniiami $v$ ispolnenie vstupivshikh $v$ silu postanovleniy po delam ob administrativnykh pravonarusheniiakh $v$ chasti diagnostiki, profilaktiki, lecheniia, meditsinskoy, sotsial'noy reabilitatsii na territorii Krasnoyarskogo kraia: otchet o nauchno-issledovatel'skoy rabote (zakliuchitel'nyy) [Problematic Issues of the Social Institutions' Enforcement of the Valid Decrees for the Administrative Cases Concerning the Medical Examination, Prevention, Treatment, Medical and Social Rehabilitation in the Territory of Krasnoyarsk Region: Research Report (Final)] / N.N. Tsukanov, E.A. Dmitrieva, A.Iu. Ivanov, A.V. Zhil'tsov, A.V. Gorelik, I.V. Kudashova. Krasnoyarsk: Siberian Law Institute of the Russian Federal Service for Drug Control. 2015 .

11 See: Korobitsyna T.V. Strategiia gosudarstvennoy antinarkoticheskoy politiki do 2020 g. - obespechenie proryva v profilakticheskoy deiatel'nosti? [Federation National Anti-Drug Policy Until 2020 - Providing Breakthru in Preventive Activities?] // Newsletter of Siberian Law Institute of the Russian Federal Service for Drug Control. 2010. No.4, P. 142.

12 See: par. 2 part 3 of article 3 of the Federal Law No.46-FZ of April 06, 2011 "On the issue of administrative surveillance of returned convicts".

13 See: par.5 of article 13 of the Federal Law No.150-FZ of December 13, 1996, "On weapon”.

14 See: part 1 of article 28 of the Federal Law No.196-FZ of December 10, 1995 "On traffic safety".

15 See: article 20 of the Federal Law No.323-FZ of November 21, 2011 "On the basics of public health of the citizens of the Russian Federation" // Legislation of the Russian Federation. 2011. No. 48, article 6724.

16 Zhdanov N.M., Solovey Iu.P. Administrativno-pravovaia bor'ba s p'ianstvom i alkogolizmom: uchebnoe posobie [Administrative and Legal Fight Against Alcohol Abuse and Alcoholism: Teaching Aids]. Omsk: Vysshaia Shkola MVD SSSR, 1987. P. 38

17 See: Sobranie zakonodatel'stva Rossiyskoy Federatsii [The Collection of the Legislation of the Russian Federation]. 1998. No.2, Article 219.

18 Solovey Iu.P. Pravovoe regulirovanie deiatel'nosti militsii v Rossiyskoy Federatsii [Legal Regulation of the Police Activities in the Russian Federation]. Omsk: VSHM MVD Rossii, 1993, P.255.

19 For more details see: Osnovaniia administrativnoy otvetstvennosti za administrativnye pravonarusheniia, dela o kotorykh vprave vozbuzhdat' sotrudniki organov po kontroliu za oborotom narkoticheskikh sredstv i psikhotropnykh veshchestv: uchebnoe posobie [Grounds for the Administrative Liability for the Administrative Offences Included into the Jurisdiction of the Narcotic Drugs and Psychotropic Substances Circulation Control Bodies: teaching aids] / edited by Doctor of Law N.N. Tsukanov. Krasnoyarsk: Siberian Law Institute of the Russian Federal Service for Drug Control, 2014, P.86.

20 Tsukanov N.N. Federal'nyy zakon ot 25 noiabria 2013 g. No.313-FZ "O vnesenii izmeneniy v otdel'nye zakonodatel'nye akty Rossiyskoy Federatsii": novoe $v$ administrativno-deliktnom zakonodatel'stve $i$ prognoziruemye problemy pravoprimenitel'noy praktiki [Federal Law No. 313-FZ of November 25, 2013 " On introducing amendments to certain legislative acts of the Russian Federation": Innovations in the Administrative and Tort Law and the Forecasted Problems of Law Enforcement Practice"] // Newsletter of Siberian Law Institute of the Russian Federal Service for Drug Control. 2014, No.1, P.11. 
21 For more details, see: Osnovaniia administrativnoy otvetstvennosti za administrativnye pravonarusheniia, dela o kotorykh vprave vozbuzhdat' sotrudniki organov po kontroliu za oborotom narkoticheskikh sredstv i psikhotropnykh veshchestv: uchebnoe posobie [Grounds for Administrative Liability for the Administrative Offences that Be Brought Legal Proceedings Against By the Narcotic Drugs and Psychotropic Substances Circulation Control Bodies: Teaching Aids]. P. 86-94.

22 See: Sobranie zakonodatel'stva Rossiyskoy Federatsii [The Collection of the Legislation of the Russian Federation]. 2014. No.22, article 2889.

23 For example, see: Prikaz Minzdrava Rossii ot 15.11.2012 No.929n "Ob utverzhdenii Poriadka okazaniia meditsinskoy pomoshchipo profiliu "narkologiia”, [Order of the Ministry of Public Health of Russia No.929n of 15.11.2012 "On Establishment of the Procedure of Medical Assistance Concerning Addiction" // Rossiyskaya Gazeta. 203. April 25, 90/1.

24 Particularly: a) Order of the Russian Federal Service for Drug Control No.271 of July 1, 2014 "On establishment of working procedures for the narcotic drugs and psychotropic substances circulation control bodies for the control over the fulfilment of the obligation on undergoing diagnostics, preventive activities, drug addiction treatment and (or) medical and (or) social rehabilitation due to narcotic drugs or psychotropic substances consumption without medical approval, imposed on the person by the court"; b) Order of the Directorate of Russian Federal Service for Drug Control in Krasnoyarsk Region No. 155 of July 17, 2014 "On organization of the fulfilment of the Working Procedure for the narcotic drugs and psychotropic substances circulation control bodies for the control over the fulfilment of the obligation on undergoing diagnostics, preventive activities, drug addiction treatment and (or) medical and (or) social rehabilitation due to narcotic drugs or psychotropic substances consumption without medical approval, imposed on the person by the court, approved by the Order of the Russian Federal Service for Drug Control No 271 of July 1, 2014"; c) Order of the Directorate of Russian Federal Service for Drug Control in Krasnoyarsk Region No.169 of August 12, 2014 "On creation of a supernumerary group in order to fulfil the requirements of the Federal Law No.313-FZ of November 25, 2013 "On introducing amendments to certain legislative acts of the Russian Federation" and organization of its cooperation with the operating units of the Directorate"; d) recommendations on the organization and the procedure of interaction between the subdivisions of the Directorate of Russian Federal Service for Drug Control in Krasnoyarsk Region with the courts, medical organizations and social institutions on the fulfilment of the provisions of the Decree of the Government of the Russian Federation No.484 of May 28, 2014 "On establishment of regulations for the control over the fulfilment of the obligation imposed on a person by the court on undergoing medical examination, preventive activities, drug addiction treatment and (or) medical and (or) social rehabilitation due to narcotic drugs or psychotropic substances consumption without medical approval during the assignment of an administrative penalty".

25 See: Praktika realizatsii sudami na territorii Krasnoiarskogo kraia polozheniy federal'nogo zakona ot 25.11.2013 No.313FZ. Problemnye voprosy provedeniia meditsinskimi i sotsial'nymi uchrezhdeniiami $v$ ispolnenie vstupivshikh $v$ silu postanovleniy po delam ob administrativnykh pravonarusheniiakh $v$ chasti diagnostiki, profilaktiki, lecheniia, meditsinskoy, sotsial'noy reabilitatsii na territorii Krasnoiarskogo kraia [Krasnoyarsk Region Courts' Practice of Implementation of the Provisions of the Federal Law No.313-FZ Of November 25, 2013. Problematic Issues of Execution of the Valid Resolutions on the Administrative Offence Cases by the Medical and Social Institutions Concerning Diagnostics, Preventive Actions, Treatment, Medical and Social Rehabilitation in the Territory of Krasnoyarsk Region]: scientific and research work report (final) / N.N. Tsukanov, E.A. Dimitrova, A.Iu. Ivanov, A.V. Zhil’tsov, A.V. Gorelik, I.V. Kudashova. Krasnoyarsk: Siberian Law Institute of the Russian Federal Service for Drug Control. 2015. P.61.

26 See: Praktika realizatsii sudami na territorii Krasnoiarskogo kraia polozheniy federal'nogo zakona ot 25.11.2013 No.313FZ. Problemnye voprosy provedeniia meditsinskimi i sotsial'nymi uchrezhdeniiami $v$ ispolnenie vstupivshikh $v$ silu postanovleniy po delam ob administrativnykh pravonarusheniiakh v chasti diagnostiki, profilaktiki, lecheniia, meditsinskoy, sotsial'noy reabilitatsii na territorii Krasnoiarskogo kraia [Krasnoyarsk Region Courts' Practice of Implementation of the Provisions of the Federal Law No.313-FZ Of November 25, 2013. Problematic Issues of Execution of the Valid Resolutions on the Administrative Offence Cases by the Medical and Social Institutions Concerning Diagnostics, Preventive Actions, Treatment, Medical and Social Rehabilitation in the Territory of Krasnoyarsk Region]: scientific and research work report (final) / N.N. Tsukanov, E.A. Dimitrova, A.Iu. Ivanov, A.V. Zhil'tsov, A.V. Gorelik, I.V. Kudashova. Krasnoyarsk: Siberian Law Institute of the Russian Federal Service for Drug Control. 2015. P. 30.

27 See: Tsukanov N.N. Teoriia i praktika proizvodstva po delam ob administrativnykh pravonarusheniiakh, osushchestvliaemogo organami vnutrennikh del [Theory and Practice of Proceedings on the Administrative Offences Initiated by the Internal Affairs Bodies]: monograph / N.N. Tsukanov, edited by Iu.P. Solovey. Krasnoyarsk: Siberian Law Institute of the Russian Federal Service for Drug Control, 2012. P. 62; Tsukanov N.N. O printsipe publichnosti v proizvodstve po delam ob administrativnykh pravonarusheniiakh [On Publicity Principle in Proceedings on Administrative Offences] // Administrativnoe pravo i protsess. 2008. No.4.

28 See: Tsukanov N.N. Obiazannost' proyti lechenie ot narkomaii kak mera administrativnoy otvetstvennosti [Obligation to Undergo Drug Addiction Treatment as an Administrative Liability Measure] // Current Problems of Administrative Liability: proceedings of the international scientific and practical conference (Omsk, May 16, 2014) / edited by Iu.P. Solovey. Omsk: Omsk Academy of Law, 2014. P. 95-96.

\section{References}

Kodeks Rossiyskoy Federatsii ob administrativnykh pravonarusheniiakh. Glavy 1-10: postateynyy nauchno-prakticheskiy kommentariy [Administrative Offences Code of the Russian Federation, 
Chapters 1-10: Article-Wise Scientific and Practical Commentary" (edited by B.V. Rossinsky) // SPS Konslutant Plus.

Osnovaniia administrativnoy otvetstvennosti za administrativnye pravonarusheniia, dela o kotorykh vprave vozbuzhdat' sotrudniki organov po kontroliu za oborotom narkoticheskikh sredstv i psikhotropnykh veshchestv: uchebnoe posobie [Grounds for the Administrative Liability for the Administrative Offences Included into the Jurisdiction of the Narcotic Drugs and Psychotropic Substances Circulation Control Bodies: teaching aids] / edited by Doctor of Law N.N. Tsukanov. Krasnoyarsk: Siberian Law Institute of the Russian Federal Service for Drug Control, 2014.

Praktika primeneniia st.82.1 UK RF v 2012 g. (na primere Krasnoyarskogo kraia): otchiot o nauchno-issledovatel'skoy rabote [The Practice of Implementation of Article 82.1 of the Criminal Offences Code of the Russian Federation in the Year 2012 (in Krasnoyarsk Region): Research Report / Siberian Law Institute of the Russian Federal Service for Drug Control; supervised by V.N. Vinokurov, written by D.N. Tokmantsev et al., official registration No. 01201351041. Krasnoyarsk, 2012.

Praktika realizatsii sudami na territorii Kransoyarskogo kraia polozheniy federal'nogo zakona ot 25.11.2013 No.313-FZ. Problemnye voprosy privedeniia meditsinskimi i sotsial'nymi uchrezhdeniiami $v$ ispolnenie vstupivshikh $v$ silu postanovleniy po delam ob administrativnykh pravonarusheniiakh $v$ chasti diagnostiki, profilaktiki, lecheniia, meditsinskoy, sotsial'noy reabilitatsii na territorii Krasnoyarskogo kraia: otchiot o nauchno-issledovatel'skoy rabote (zakliuchitel'nyy) [Problematic Issues of the Social Institutions' Enforcement of the Valid Decrees for the Administrative Cases Concerning Medical Examination, Prevention, Treatment, Medical and Social Rehabilitation in the Territory of Krasnoyarsk Region: Research Report (Final)] / N.N. Tsukanov, E.A. Dmitrieva, A.Iu. Ivanov, A.V. Zhil'tsov, A.V. Gorelik, I.V. Kudashova. Krasnoyarsk: Siberian Law Institute of the Russian Federal Service for Drug Control. 2015.

Dimitrova E.A. Analiz deiatel'nosti negosudarstvennykh ob'edineniy $v$ sfere reabilitatsii narkozavisimykh [The Review of Activities Carried Out by Non-Governmental Institutions in the Field of Drug Addicts Rehabilitation]: analytical review. Krasnoyarsk, 2014.

Dimitrova E.A. Reabilitatsiia narkozavisimykh lits kak mera preduprezhdeniia prestupnosti, sviazannoy s nezakonnym oborotom narkoticheskikh sredstv i psikhotropnykh veshchestv [Drug Addicts Rehabilitation as a Preventive Measure Against Crimes Associated with Illegal Narcotic Drugs and Psychotropic Substances Circulation] // Proceedings of the 17th International Scientific and Practical Conference (April 17-18, 2014) "Current Problems of the Drug Addiction Prevention and the Countermeasures Against the Legal Offences in the Field of Legal and Illegal Drug Circulation: National and International Levels": in 2 parts. Edited by I.A. Medvedev. Krasnoyarsk, 2014, part 2

Fiodorov A.V. Vzaimosviaz' nezakonnogo potrebleniia narkotikov $i$ ikh nezakonnogo oborota [Interconnection Between Illegal Drug Consumption and Illegal Drug Circulation] // Narkokontrol', 2013, No.3.

Gazizov D.A., Gazizova T.G. Problemy primeneniia zakonodatel'stva ob administrativnykh pravonarusheniiakh $v$ sfere oborota narkoticheskikh sredstv ili psikhotropnykh veshchestv [Problems of Application of the Administrative Offences Legislation in the Field of Narcotic Drugs or Psychotropic Substances Circulation] // Administrativnoe pravo i protsess, 2012, No.3. 
Ivanov V.P. Neobkhodimost' sozdaniia novoy sfery reabilitatsii kak otvet na vyzovy sovremennykh obshchestv [The Necessity of Creating a New Sphere of Rehabilitation as a Reaction to the Modern Social Challenges] // Narkologiia 2014, No. 5.

Kalachiov B.F. Lechit' nel'zia prinudit' [We Can Treat Not Force] // Narkokontrol', 2013, No.2.

Kilin A.Z. $K$ voprosu ob aktual'nosti realizatsii na territorii kraia Federal'nogo zakona or 25 noiabria $2013 \mathrm{~g}$. [To the Problem of the Urgency of Implementation of the Federal Law No.313-FZ of November 25, 2013, in the Territory of the Region] // Proceedings of the $18^{\text {th }}$ International Scientific and Practical Conference (April 16-17, 2015) "National and International Levels of Countermeasures Against the Drug Threat and Cooperation in the Field of Rehabilitation and Resocialization of Drug Consumers": in 2 parts. Edited by I.A. Medvedev, Siberian Law Institute of the Russian Federal Service for Drug Control, 2015. Part 2.

Korobitsyna T.V. Problemy ispol'zovaniia reabilitatsionnykh tekhnologiy [Rehabilitation Technology Application Challenges] // Razvitie sistemy reabilitatsii i resotsializatsii narkozavisimykh [Drug Addicts Rehabilitation and Resocialization System Development]: educational materials. Irkutsk, 2013.

Korobitsyna T.V. Strategiia gosudarstvennoy antinarkoticheskoy politiki do 2020 g. obespechenie proryva v profilakticheskoy deiatel'nosti? [Federation National Anti-Drug Policy Until 2020 - Providing Breakthru in Preventive Activities?] // Newsletter of Siberian Law Institute of the Russian Federal Service for Drug Control. 2010. No.4.

Novikova T.A. Sovershenstvovanie administrativno-pravovogo mekhanizma vozdeystviia na nezakonnoe potreblenie narkotikov [Improvement of Administrative and Legal Mechanism of Illegal Drug Consumption Treatment]: dissertation for the academic degree of the Candidate of Law. Lyubertsy, 2014.

Otkidach A.O. O pravovom mekhanizme pobuzhdeniia $k$ otkazu ot potrebleniia narkotikov $i$ vyboru lecheniia i kompleksnoy reabilitatsii [On the Legal Mechanism of Encouraging the Treatment of Drug Addiction and Selection of Treatment and an Integrated Rehabilitation] // Proceedings of the All-Russian Scientific and Practical Conference of November 26, 2012 "To the 10 $0^{\text {th }}$ Anniversary of the Russian Federal Service for Drug Control. New Legislation and the Challenges of Law Enforcement Practice in the Combat Against Drug Crime”, Moscow, part 2. Moscow, 2013.

Saiadan S.G. Primenenie otsrochki otbyvaniia nakazaniia bol'nym narkomaniey $i$ novelly rossiyskogo antinarkoticheskogo zakonodatel'stva [Application of Deferral of Punishment to Drug Addicts and Novelties of Russian Drug Law Enforcement] // Meditsinskoe pravo, 2015, No.1.

Shchedrin N.V. O prinuditel'nom lechenii lits, stradaiushchikh alkogolizmom i narkomaniey [On Compulsory Treatment of Alcoholics and Drug Addicts] // Narkokontrol', 2013, No.3.

Solovey Iu.P. Pravovoe regulirovanie deiatel'nosti militsii v Rossiyskoy Federatsii [Legal Regulation of the Police Activities in the Russian Federation]. Omsk, 1993.

Tsukanov N.N. Federal'nyy zakon ot 25 noiabria 2013 g. No.313-FZ "O vnesenii izmeneniy $v$ otdel'nye zakonodatel'nye akty Rossiyskoy Federatsii”: novoe $v$ administrativno-deliktnom zakonodatel'stve i prognoziruemye problemy pravoprimenitel'noy praktiki [Federal Law No. 313FZ of November 25, 2013 “ On introducing amendments to certain legislative acts of the Russian Federation": Innovations in the Administrative and Tort Law and the Forecasted Problems of Law 
Enforcement Practice"] // Newsletter of Siberian Law Institute of the Russian Federal Service for Drug Control. 2014, No.1.

Tsukanov N.N. O printsipe publichnosti $v$ proizvodstve po delam ob administrativnykh pravonarusheniiakh [On Publicity Principle in Proceedings on Administrative Offences] // Administrativnoe pravo i protsess. 2008. No.4.

Tsukanov N.N. Obiazannost' proyti lechenie ot narkomaii kak mera administrativnoy otvetstvennosti [Obligation to Undergo Drug Addiction Treatment as an Administrative Liability Measure] // Current Problems of Administrative Liability: proceedings of the international scientific and practical conference (Omsk, May 16, 2014) / edited by Iu.P. Solovey. Omsk: Omsk Academy of Law, 2014..

Tsukanov N.N. Stat'ia 6.9.1 KoAP RF: prognoziruemye voprosy i problemy prakticheskogo primeneniia [Article 6.9.1 of the Administrative Offences Code of the Russian Federation: Forecasted Challenges and Problems of Law Enforcement Practice] / Proceedings of the $17^{\text {th }}$ International Scientific and Practical Conference (April 17-18, 2014) "Current Problems of Preventing Drug Addiction and Counteraction against Offences in the Field of Legal and Illegal Drug Circulation: National and International Levels": in 2 parts / edited by I.A. Medvedev. Krasnoyarsk, 2014, part 2.

Tsukanov N.N. Teoriia ipraktika proizvodstva podelam obadministrativnykh pravonarusheniiakh, osushchestvliaemogo organami vnutrennikh del [Theory and Practice of Proceedings on the Administrative Offences Initiated by the Internal Affairs Bodies]: monograph / N.N. Tsukanov, edited by Iu.P. Solovey. Krasnoyarsk, 2012.

Zhdanov N.M., Solovey Iu.P. Administrativno-pravovaia bor'ba s p'ianstvom i alkogolizmom: uchebnoe posobie [Administrative and Legal Fight Against Alcohol Abuse and Alcoholism: Teaching Aids]. Omsk: Vysshaia Shkola MVD SSSR, 1987. P. 38.

Zvonov A.V. Voprosy otvetstvennosti osuzhdionnykh, bol'nykh narkomaniey, otbyvanie nakazaniia kotorym otsrocheno: obshchaia otsenka [General Assessment of Legal Responsibility Issues in Respect to the Convicted Drug Addicts with Deferred Penalty] // Ugolovno-ispolnitel'naia sistema: pravo, ekonomika, upravlenie, 2014, No.1. 


\title{
Возложение обязанности пройти диагностику, профилактические мероприятия, лечение \\ от наркомании и (или) медицинскую \\ и (или) социальную реабилитацию \\ в связи с потреблением наркотических средств \\ или психотропных веществ без назначения врача \\ либо новых потенциально опасных \\ психоактивных веществ \\ как средство противодействия наркоугрозе: \\ перспективы и проблемы реализации
}

Н.Н. Цуканов

Сибирский федеральный университет Россия, 660041, Красноярск, пр. Свободньій, 79

\begin{abstract}
В статье рассматриваются вопросы, связанные с реализачией ч. $2.1 \mathrm{~cm} .4 .1$ КоАП РФ, в соответствии с которой при назначении административного наказания за совершение административных правонарушений в области законодательства о наркотических средствах, психотропных веществах и об их прекурсорах лииу, признанному больным наркоманией либо потребляющему наркотические средства или психотропные вещества без назначения врача либо новые потенциально опасные психоактивные вещества, суд может возложить на такое лицо обязанность пройти диагностику, профилактические мероприятия, лечение от наркомании и (или) медицинскую и (или) социильную реабилитацию в связи с потреблением наркотических средств или психотропных веществ без назначения врача либо новых потенщиально опасных психоактивных веществ.

Анализируются проблемы, возникающие в практической деятельности органов наркоконтроля, формулируются возможные варианты и оцениваются перспективы их решения.

Ключевые слова: диагностика, профилактические мероприятия, лечение от наркомании, медииинскаяреабилитация, социальнаяреабилитация, наркотическиесредства, психотропные вещества, новые потенииально опасные психоактивные вещества, наркоугроза.
\end{abstract}

Научная специальность: 12.00.00 - юридические науки. 